\section{Kidney \\ Blood Pressure Research}

\title{
A Role of Intestinal Alkaline Phosphatase 3 (Akp3) in Inorganic Phosphate Homeostasis
}

\author{
Shohei Sasaki ${ }^{a}$ Hiroko Segawa ${ }^{a}$ Ai Hanazakia Ruri Kirino ${ }^{a}$ Toru Fujii ${ }^{a}$ \\ Kayo Ikuta ${ }^{a}$ Miwa Noguchia Sumire Sasaki ${ }^{a}$ Megumi Koike ${ }^{a} K^{2}$ azuya Tanifujia \\ Yuji Shiozaki $^{a}$ Ichiro Kaneko ${ }^{a}$ Sawako Tatsumi ${ }^{a}$ Takaaki Shimohata ${ }^{b}$ \\ Yoshichika Kawaic Sonoko Narisawa ${ }^{d}$ José Luis Millán ${ }^{d}$ Ken-ichi Miyamotoa \\ aDepartment of Molecular Nutrition, Institute of Biomedical Sciences, University of Tokushima Graduate \\ School, Tokushima; ${ }^{\mathrm{b}}$ Department of Preventive Environment and Nutrition, Institute of Biomedical \\ Sciences, University of Tokushima Graduate School, Tokushima; 'Department of Food Science, Institute \\ of Biomedical Sciences, University of Tokushima Graduate School, Tokushima, Tokushima, Japan, \\ 'Sanford Children's Health Research Center, Sanford Burnham Prebys Medical Discovery Institute, La \\ Jolla, California, United States
}

\section{Key Words}

Hyperphosphatemia $\cdot$ CKD-MBD $・$ Phosphate transporter

\begin{abstract}
Background/Aims: Hyperphosphatemia is a serious complication of late-stage chronic kidney disease (CKD). Intestinal inorganic phosphate $(\mathrm{Pi})$ handling plays an important role in $\mathrm{Pi}$ homeostasis in CKD. We investigated whether intestinal alkaline phosphatase 3 (Akp3), the enzyme that hydrolyzes dietary Pi compounds, is a target for the treatment of hyperphosphatemia in CKD. Methods: We investigated Pi homeostasis in Akp3 knockout mice $\left(\mathrm{Akp3}^{-/-}\right)$. We also studied the progression of renal failure in an $\mathrm{Akp}^{{ }^{--}}$mouse adenine treated renal failure model. Plasma, fecal, and urinary $\mathrm{Pi}$ and $\mathrm{Ca}$ concentration were measured with commercially available kit, and plasma fibroblast growth factor 23, parathyroid hormone, and $1,25(\mathrm{OH})_{2} \mathrm{D}_{3}$ concentration were measured with ELISA. Brush border membrane vesicles were prepared from mouse intestine using the $\mathrm{Ca}^{2+}$ precipitation method and used for Pi transport activity and alkaline phosphatase activity. In vivo intestinal $\mathrm{Pi}$ absorption was measured with oral ${ }^{32} \mathrm{P}$ administration. Results: Akp3 ${ }^{--}$mice exhibited reduced intestinal type II sodiumdependent Pi transporter (Npt2b) protein levels and $\mathrm{Na}$-dependent $\mathrm{Pi}$ co-transport activity. In addition, plasma active vitamin $\mathrm{D}$ levels were significantly increased in $\mathrm{Akp3}^{-/-}$mice compared with wild-type animals. In the adenine-induced renal failure model, Akp3 gene deletion suppressed hyperphosphatemia. Conclusion: The present findings indicate that intestinal
\end{abstract}

\footnotetext{
Hiroko Segawa, PhD Department of Molecular Nutrition, Institute of Health Biosciences, University of Tokushima Graduate School 3-18-15 Kuramoto-Cho, Tokushima City 770-8503 (Japan)

Tel. +81-88-633-7081, Fax +81-88-633-7082, E-Mail segawa@tokushima-u.ac.jp
} 


\section{Kidney Blood Pressure Research}

Kidney Blood Press Res 2018;43:1409-1424

\begin{tabular}{l|l}
\hline DOI: $10.1159 / 000493379$ & (C) 2018 The Author(s). Published by S. Karger AG, Basel
\end{tabular}

Published online: 10 September, 2018 www.karger.com/kbr

Sasaki et al.: Relationship Between Akp3 and Npt2b in the Gut

Akp3 deletion affects $\mathrm{Na}^{+}$-dependent $\mathrm{Pi}$ transport in the small intestine. In the adenineinduced renal failure model, Akp3 is predicted to be a factor contributing to suppression of the plasma Pi concentration.

\section{Introduction}

An elevated serum inorganic phosphate (Pi) level is an independent risk factor for mortality, and treatment with Pi binders is independently associated with improved survival in chronic kidney disease (CKD) patients [1,2]. Findings from experimental studies support the epidemiologic findings: clinical practice guidelines recommend specific targets for serum Pi levels in dialysis patients [3-5]. As prevention and correction of hyperphosphatemia is a major goal of the treatment of CKD - mineral and bone disorder, special attention must be focused on Pi balance.

Pi balance is maintained by intestinal absorption, renal excretion, and bone accretion. At least two types of sodium-dependent Pi co-transporters, solute carrier (SLC)34 and SLC20, are expressed in the kidney and intestine. In CKD, Pi absorption in the small intestine has an important role in Pi homeostasis. SLC34A2/Npt2b mediates intestinal transcellular Pi transport at the apical side of epithelial cells $[6,7]$. Several research groups, including ours, have studied the regulation of intestinal Npt $2 \mathrm{~b}$ by vitamin D, nicotinamide (NAM), and dietary Pi $[8,9]$. In addition, we developed an Npt2b inhibitor that blocks intestinal Pi transport and renal Pi excretion [10]. Recent studies demonstrated that Npt2b-null mice exhibit suppressed $\mathrm{Na}^{+}$-dependent Pi transport in the apical membrane of intestinal epithelial cells and decreased renal Pi excretion [11-13]. In a renal failure model of adenine administration in Npt2b knockout (KO) mice, the serum Pi concentration is significantly suppressed [11, $12,14]$. These studies indicate that $\mathrm{Npt} 2 \mathrm{~b}$ is an important target for the treatment of CKDassociated hyperphosphatemia.

The main segment of the small intestine for Pi absorption in humans and rats differs from that in mice [15-18]. The ileum in mice has the highest transcellular Pi transport activity, while the jejunum in humans and rats has the highest Pi transport activity [15-20]. In rats, multiple transport systems are involved in intestinal Pi absorption [21].

In humans, rats, and mice, intestinal alkaline phosphatase (IAP) is expressed throughout the gastrointestinal tract with the highest expression in the duodenum and much lower expression in the jejunum, ileum, and colon [22]. IAP is a brush border phosphomonoesterase that catalyzes the hydrolysis of nonspecific Pi ester bonds at an alkaline $\mathrm{pH}$, and a plasma membrane-bound glycoprotein that dephosphorylates several substrates [23-26], including $\mathrm{Pi}$ additives. The mouse gut expresses three IAP isozymes: Akp3, which is expressed specifically in the duodenum after weaning; Akp5, which is expressed at very low levels throughout the gut; and Akp6, which is expressed at high levels throughout the gut [27]. Akp3 KO $\left(\mathrm{Akp}^{-\%}\right)$ mice have no overt intestinal phenotype. Akp3 ${ }^{-/}$mice fed a high fat diet become obese, and develop hyperlipidemia and hepatic steatosis [25, 28]. These changes are accompanied by an upregulation of Akp6 and FAT/CD36, a fatty acid transporter, suggesting that Akp3 negatively regulates fat absorption [24, 29]. Thus, IAP activity helps regulate intestinal lipid absorption and surfactant-like protein secretion, in addition to hydrolyzing ingested organic Pi.

Several studies demonstrated that extracellular purines, notably ATP, serve as endogenous substrates for IAP [30-32]. To access the IAP catalytic site, ATP is presumably released from the enterocytes into the luminal space. Malo et al. showed that Akp3 $\%$ mice have high luminal ATP concentrations, which affects bacterial growth in the gut [33]. Changes in the extracellular ATP concentration affect Pi transport [34-36]. In addition, extracellular ATP is expected to suppress Pi transporters [35]. Therefore, we hypothesize that increased luminal ATP levels inhibit intestinal Pi absorption in Akp3\% mice. 


\section{Kidney Blood Pressure Research}

The relationship between IAP and Pi metabolism is not clear. IAP hydrolyzes Pi compounds, however, and it is thus expected that IAP is associated with dietary Pi digestion and absorption, especially in people consuming a Western diet, which generally contains many Pi additives. Using isolated renal brush border membrane vesicles (BBMVs), Storelli and Murer compared sodium-dependent transport of Pi and alkaline phosphatase activity. They showed no correlation between alkaline phosphatase activity and rate of Pi transport [37]. Furthermore, Shirazi et al., investigating the link between Pi transport and alkaline phosphatase in brush border membranes from rat small intestine, demonstrated that alkaline phosphatase inhibition does not affect the Pi transport system [38]. Kempson et al. showed that dietary Pi levels affect intestinal alkaline phosphatase activity and may be involved in Pi absorption [39]. Thus, the role of intestinal alkaline phosphatase in Pi absorption remains unclear.

Here we performed three experiments to evaluate the following: 1) the relationship between IAP and Pi transport (Npt2b levels), 2) the phenotype of Akp3 $\%$, and 3) the effect of Akp3 on Pi metabolism in animals with adenine-induced renal insufficiency. Our findings indicated that Akp3 is an important regulator of Npt2b and intestinal Pi transport in mice.

\section{Materials and Methods}

\section{Animals and Diet}

Mice were maintained under pathogen-free conditions and handled in accordance with the Guidelines for Animal Experimentation of Tokushima University School of Medicine. For wild-type mice, male C57BL/6J mice were purchased from Charles River Laboratories Japan (Yokohama, Japan). Akp3\% mice were generated as described previously [25]. Crossing male and female Akp3 ${ }^{+/-}$mice yielded Akp3 ${ }^{+/+}$and Akp3/-/ mice. Genomic DNA was extracted from tail clippings and amplified by polymerase chain reaction (PCR) using specific primers, as described previously (Table 1) [25]. Mice were weaned at 4 weeks of age, and provided free access to water and standard mouse chow (1.06\% Ca and $0.99 \%$ Pi; CLEA Japan, Inc., Tokyo, Japan).

For the dietary adaptation study, mice were fed a test diet (low $\mathrm{Pi} ; 0.02 \% \mathrm{Pi}$, control Pi; $0.6 \% \mathrm{Pi}$, and high $\mathrm{Pi} ; 1.2 \% \mathrm{Pi}$ ) for 7 days. $\mathrm{KH}_{2} \mathrm{PO}_{4}$ was used for this dietary adaptation.

Adenine-induced nephritis was produced in mice by oral gavage of adenine dissolved in vehicle (carboxymethyl cellulose) [12]. Eleven-week-old male mice were administered adenine (50-100 mg/kg body weight) 3 times per week. Control mice were orally administered an equivalent volume of vehicle. The experimental schedule was described previously [12].

\section{Metabolic cages to collect urine and feces samples}

Mice were individually caged to collect 24-h urine and feces samples. Fecal samples were ashed using a modified protocol [40]. The fecal samples were collected and placed into beakers to dry at $110^{\circ} \mathrm{C}$ for up to $24 \mathrm{~h}$. The samples were then ashed at $250^{\circ} \mathrm{C}$ for $3 \mathrm{~h}$ and $550^{\circ} \mathrm{C}$ for $24 \mathrm{~h}$ in a muffle furnace. The samples were cooled, weighed, and digested in $\mathrm{HCl}$ with heat, and the sample volume was standardized to $5 \mathrm{ml}$.

\section{Pi, Ca, Cre, FGF23, and PTH concentrations}

Concentrations of plasma or urinary inorganic Pi, calcium (Ca), and creatinine (Cre) were determined using commercial kits (Wako, Osaka, Japan). Concentrations of plasma intact fibroblast growth factor 23 (FGF23) proteins and parathyroid hormone (PTH) were determined using the FGF23 ELISA kit (KAINOS Laboratories, Tokyo, Japan) and intact PTH ELISA kit (Immunotopics Inc., San Clemente, CA), respectively. Metabolic cages were used to collect the 24-h urine samples.

Table 1. Primers for genotyping

\begin{tabular}{lcc}
\hline Primer name & & \multicolumn{1}{c}{ Sequences } \\
\hline Akp3 & Sense & AGTTCAGTTCCCACATACCTGG \\
(WT allele) & Antisense & CCAAACATACTGGGATCCCTAG \\
Akp3 & Sense & TGTGCTCGACGTTGTCACTGAA \\
(Targeted allele) & Antisense & CGATACCGTAAAGCACGAGG
\end{tabular}




\section{Kidney Blood Pressure Research}

Sasaki et al.: Relationship Between Akp3 and Npt2b in the Gut

\section{RNA extraction and $c D N A$ synthesis}

Total RNA was extracted from mouse tissues using ISOGEN (Wako, Osaka Japan) according to the manufacturer's instructions. After treatment with DNase I (Invitrogen, Carlsbad, CA), cDNA was synthesized using the Moloney murine leukemia virus, reverse transcriptase (Invitrogen), and oligo(dT)12-18 primer.

\section{Quantitative PCR}

Quantitative PCR was performed using ABI PRISM 7500 (Applied Biosystems, Foster City, CA). The reaction mixture comprised $10 \mathrm{ml}$ of SYBR Premix Ex Taq, ROX Reference Dye II (Perfect Real Time, Takara, Osaka, Japan), and specific primers. The PCR reactions were initiated with denaturation at $95^{\circ} \mathrm{C}$ for $10 \mathrm{~s}$, and annealing at $60^{\circ} \mathrm{C}$ for $15 \mathrm{~s}$ and at $72^{\circ} \mathrm{C}$ for $15 \mathrm{~s}$. Data were evaluated with SDS v. 1.2X with RQ software. The PCR primer sequences are shown in Table 2.

\section{Protein sample purification}

BBMVs were prepared from mouse intestine and kidneys using the $\mathrm{Ca}^{2+}$ precipitation method, as described previously. Protein concentrations were measured using the BCA protein assay kit (Pierce, Rockford, IL).

\section{Antibodies}

Polyclonal rabbit anti-Npt2a and Npt2c antibodies were generated as described previously [41]. Polyclonal rabbit anti-Npt2b antibody was purchased from Alpha Diagnostic International (San Antonio, TX). Polyclonal rabbit anti-Akp3, Akp5, and Akp6 antiserum were used as described previously [24].

\section{Immunoblotting}

Protein samples were denatured with 2-mercaptoethanol and subjected to $8 \%$ or $10 \%$ sodium dodecyl sulfate-polyacrylamide gel electrophoresis. The separated proteins were transferred by electrophoresis to Immobilon-P polyvinylidene difluoride (Millipore, Billerica, MA) and then treated with the following diluted antibodies: affinity-purified anti-Npt2a (1:2000), Npt2b (1:1000) antibodies, and Npt2c (1:3000), Akp3 (1:8000), Akp5 (1:10, 000), and $\operatorname{Akp} 6(1: 100,000)$ antiserum. Mouse anti-actin monoclonal antibody (Chemicon, Temecula, CA) was used as an internal control. Horseradish peroxidase-conjugated anti-rabbit or anti-mouse IgG was utilized as the secondary antibody (Jackson Immuno Research Laboratories, Inc., West Grove, PA), and signals were detected using Immobilon Western (Millipore).

\section{Measurement of intestinal alkaline phosphatase activity}

Proximal and distal BBMVs were used for alkaline phosphatase measurement. The proximal intestine refers to the duodenum and the proximal part of the jejunum. The distal intestine refers to the late jejunum and ileum. Intestinal BBMVs $(20 \mu \mathrm{g})$ were mixed with phosphatase assay reagent including $4 \mathrm{mM}$ disodiump-nitrophenyl $\mathrm{Pi}$ and $0.1 \mathrm{M}$ glycine ( $\mathrm{pH} \mathrm{9.0),} 1 \mathrm{mM} \mathrm{MgCl}_{2}$, and incubated at $37^{\circ} \mathrm{C}$ for $20 \mathrm{~min}$. The reaction was stopped by adding $0.05 \mathrm{mM} \mathrm{NaOH}$ to the reaction mixture. A calibration curve was prepared with p-nitrophenol and absorbance was measured at $400 \mathrm{~nm}$. Alkaline phosphatase activity per microgram protein was calculated.

\section{Measurement of intestinal ATP}

The gastrointestinal contents were washed out from the proximal and distal intestine with distilled water and vortexed vigorously. Samples were centrifuged at $3000 x$ for $10 \mathrm{~min}$ and an aliquot of the supernatant was used to determine the ATP concentration using a commercial ATP assay kit (Toyo Ink) according to the manufacturer's instructions.

Table 2. Primers for real-time PCR. 1) = 1a-Hydroxylase, 2) = 24-Hydroxylase, 3) = glyceraldehyde-3-phosphate dehydrogenase

\begin{tabular}{ccc}
\hline Primer name & & \multicolumn{1}{c}{ Sequences } \\
\hline 1aOHase $^{1)}$ & Sense & GAGCAAACTCCAGGAAGCAG \\
& Antisense & TGAGGAATGATCAGGAGAGG \\
& Sense & TGGGAAGATGATGGTGACCC \\
240Hase & \\
& Antisense & TCGATGCAGGGCTTGACTG \\
& Sense & CTGCACCACCAACTGCTTAGC \\
GAPDH $^{3)}$ & Antisense & CATCCACAGTCTTCTGGGTG
\end{tabular}




\section{Kidney Blood Pressure Research}

Measurement of Pi transport activity

BBMV Pi transport activity was measured in the mouse small intestine and kidney using a rapid filtration technique, as described previously [12].

Intestinal absorption was assessed based on the ${ }^{32} \mathrm{P}$ blood level (cpm) after gavage of a test solution using a previously described protocol with modifications [10,42]. The test solution (pH7.4) contained 128 $\mathrm{mM} \mathrm{NaCl}, 4.7 \mathrm{mM} \mathrm{KCl}, 2.5 \mathrm{mM} \mathrm{CaCl}_{2}, 1.2 \mathrm{mM} \mathrm{MgSO}_{4}$, and $4 \mathrm{mM} \mathrm{KH}_{2} \mathrm{PO}_{4}(80 \mu \mathrm{Ci} / \mathrm{ml})$. For the study, $15 \mu \mathrm{l}$ of the test solution per gram body weight was administered by gavage. Blood samples were obtained at the indicated time-points and analyzed by liquid scintillation counting.

\section{Cell culture}

The rat cell line IEC-6 (ATCC, Manassas, VA) was maintained in DMEM (Sigma-Aldrich, St. Louis, MO) supplemented with $10 \%$ FBS, as described previously $[43,44]$. BzATP triethylammonium salt, an activator of the P2X receptors, was obtained from Wako (Tokyo, Japan). Monoclonal rabbit anti-P2X7 receptor antibody was purchased from Cell Signaling (Danvers, MA).

\section{Statistical analysis}

Data are expressed as means \pm standard error of the mean. The significance of differences between two experimental groups was established by ANOVA followed by Student's $t$ test. Differences among multiple groups were analyzed by ANOVA followed by Scheffe's test. A $P$ value of less than 0.05 was considered significant.

\section{Results}

In the first set of experiments, we analyzed the effect of the dietary Pi content on IAP activity and Akp3 protein levels in the proximal and distal intestine. Plasma Ca concentrations were significantly higher in mice fed the LP diet than in mice fed the CP diet (Fig. 1A). Urinary Ca excretion levels were significantly higher in mice fed the LP diet than in the other groups (Fig. 1B). In contrast, plasma Pi and urinary Pi excretion levels were significantly lower in mice fed the LP diet than in the other groups (Fig. 1C and 1D). As described previously, IAP activity levels were markedly higher in the proximal intestine than in the distal intestine (Fig. 1E and 1F). Furthermore, IAP activity was higher in the proximal intestine, but not in the distal intestine, of mice fed the LP diet than in mice fed the high Pi diet (Fig. 1E and 1F). Akp3 mRNA is exclusively expressed in the duodenum [24]. We examined Akp3 protein expression in the proximal intestine of mice fed the LP, CP, or HP diets (Fig. 1G). Akp3 protein expression was significantly higher in the proximal intestine of mice fed the LP diet than in mice fed the CP and HP diets (Fig. 1G). Npt2b protein expression was significantly higher in the distal intestine of mice fed the LP diet than in mice fed the HP diet (Fig. 1H). These findings indicate that IAP/Akp3 is regulated by the dietary Pi content, as reported previously [39].

Next, we examined how such IAP fluctuations affect systemic Pi metabolism using Akp3 ${ }^{-1-}$ mice. Kaliannan et al. reported that Akp3 ${ }^{-/}$mice fed normal mouse chow exhibit metabolic endotoxemia and metabolic syndrome [45]. First, we examined whether Akp3 $\%$ mice fed normal chow exhibit inflammation or lipid metabolism abnormalities. We confirmed the loss of Akp3 mRNA and protein expression in the proximal intestine of Akp3 $\%$ mice (Fig. 2A and 2B). Alkaline phosphatase activity in the proximal intestine, but not the distal intestine, of Akp3 $\%$ mice was significantly decreased (Fig. 2C). In the present study, we examined Akp3\% physiology to confirm the previous findings (Fig. 2D-G). Body weight gain and the levels of lipid parameters, including total cholesterol, triglyceride, and endotoxin, which is an inflammation marker, were not altered in Akp3 $\%$ mice compared with $\mathrm{Akp3}^{+/+}$mice (Fig. 2D-2G). An intestinal permeability study using fluorescein isothiocyanatedextran revealed no significant differences between $\mathrm{Akp}^{+/+}$and Akp3 ${ }^{\%-}$ mice (Fig. $2 \mathrm{H}$ ). In a previous study, Akp3 $\%$ mice exhibited increased levels of inflammation markers [45]. 


\section{Kidney Bloód Pressure Research}

In the present study, Akp3 $\%$ animals ingesting the normal chow did not exhibit the evaluated inflammation markers (data not shown). These findings imply some genetic drift in the genome of the Akp3 $\%$ mice depending on the colony, and/ or unknown effect(s) resulting from slight differences between the control diets.

To confirm whether $\mathrm{Akp3}^{\%}$ mice have abnormal changes in $\mathrm{Ca}$ and $\mathrm{Pi}$ metabolism, we measured biologic data, intestinal and renal $\mathrm{Pi}$ transport activity, and transporter expression in Akp3 $\%$ mice. Food intake did not differ between $\quad \mathrm{Akp3}^{+/+}$ and $\mathrm{Akp}^{\%}$ mice at 9 weeks of age (Fig. 3A). Urinary volume and plasma Cre levels did not differ significantly between $\mathrm{Akp3}^{+/+}$and Akp $^{\%}$ mice (Fig. 3B and $3 \mathrm{C}$ ). Furthermore, blood, urinary, and fecal excretion levels of $\mathrm{Ca}$ and Pi did not differ significantly between $\mathrm{Akp3}^{+/+}$and $\mathrm{Akp3}^{\%}$ mice (Fig. 3D-3I).

Although plasma

FGF23 and PTH levels did not differ between $\mathrm{Akp3}^{+/+}$and Akp3 $\%$ mice, $1,25(\mathrm{OH})_{2} \mathrm{D}_{3} \quad$ levels

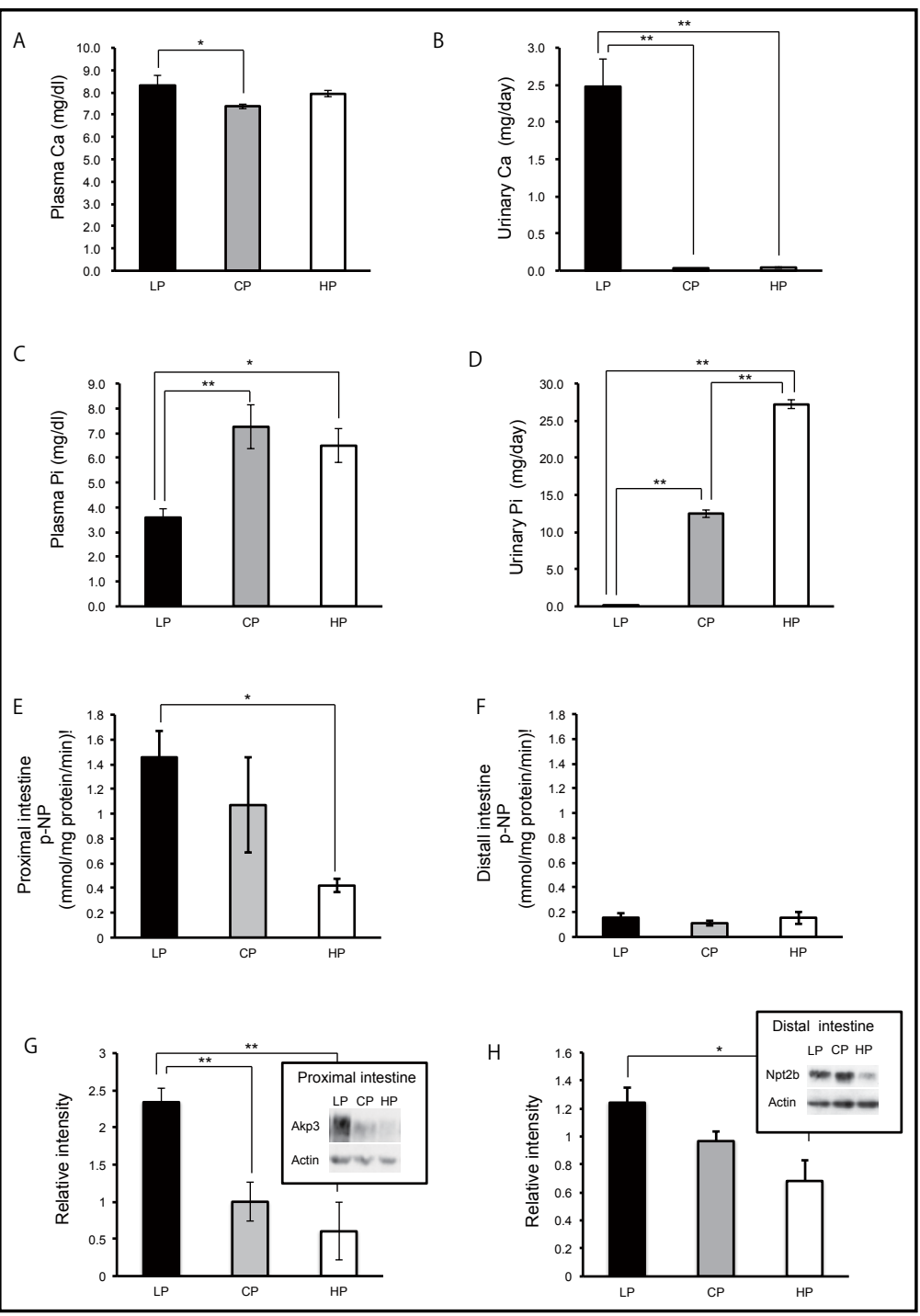

Fig. 1. Dietary Pi regulation of intestinal alkaline and phosphatase $\mathrm{Pi}$ transporter. (A-D) Metabolic cages were used for 24-h urine collection from male C57BL6 mice 9-10 weeks of age fed the low Pi (LP), control Pi (CP), or high Pi (HP) diet for 7 days (n=5-6/group). BBMVs were isolated from intestines of mice fed the LP, CP, or HP diet. (E and F) The intestines were divided into proximal and distal segments to measure alkaline phosphatase activity. Values are mean \pm SE. ${ }^{*} \mathrm{p}<0.05$. (G and $\mathrm{H}$ ) Western blotting analysis of Akp3 in the proximal intestine and intestinal sodium-dependent transporter Npt2b in the distal intestine. Actin was used as the internal control. Relative intensity values for CP were mean \pm SE. ${ }^{*} p<0.05,{ }^{* *} p<0.01$.

were significantly increased in $\mathrm{Akp} 3^{\%}$ mice compared with $\mathrm{Akp} 3^{+/+}$mice (Fig. 3J-3L). The renal $1 \alpha$-hydroxylase mRNA levels were not different between $\mathrm{Akp}^{\%}$ mice and $\mathrm{Akp}^{+/+}$ mice, whereas the renal 24-hydroxylase mRNA levels were significantly decreased in $\mathrm{Akp} \%$ mice compared with Akp3 ${ }^{+/+}$mice (Fig. 3M and 3N). 


\section{Kidney Blood Pressure Research}

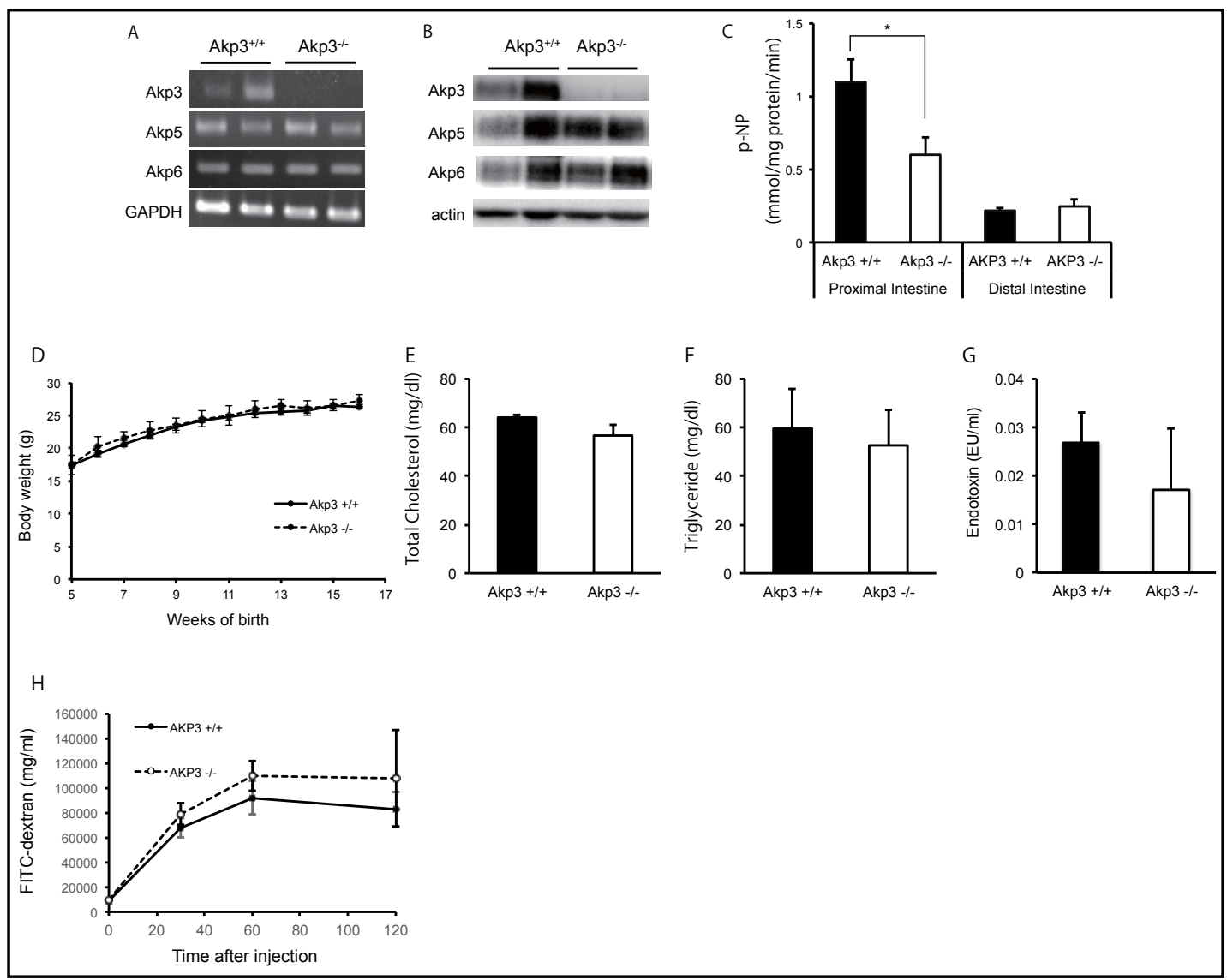

Fig. 2. Akp3 $\%$ mice fed normal chow had normal lipid metabolism. Male Akp3 ${ }^{+/+}$and Akp3 ${ }^{\%}$ mice 9-10 weeks of age ( $n=5-6 /$ group). (A) Akp3, Akp5, and Akp6 mRNA and (B) protein in the proximal intestine of $\mathrm{Akp3}^{+/+}$and $\mathrm{Akp3}^{-/-}$mice. (C) Intestines of $\mathrm{Akp3}^{+/+}$and $\mathrm{Akp}^{-/-}$mice were divided into proximal and distal segments for measurement of alkaline phosphatase activity. (D) Body weight, (E) blood total cholesterol, (F) triglyceride, and (G) endotoxin concentrations. (H) An intestinal permeability study using fluorescein isothiocyanate-dextran in male $\mathrm{Akp3}^{+/+}$and $\mathrm{Akp3}^{-\%}$ mice at 9-10 weeks of age $(\mathrm{n}=5-6)$. Values are mean $\pm \mathrm{SE}$.

Renal Pi transport activity and renal sodium-dependent transporter protein levels were not significantly different between Akp3 ${ }^{-/}$mice and $\mathrm{Akp}^{+/+}$mice (Fig. 4A and 4B). In contrast, intestinal Pi transport activity and intestinal Npt2b protein expression were significantly decreased in Akp3 $\%$ mice compared with $\mathrm{Akp}^{+/+}$mice (Fig. 4C and 4D). Previous reports revealed that extracellular or intracellular ATP levels regulate $\mathrm{Na}^{+}$-dependent Pi transport activities in the proximal tubular cells $[34,46]$. To determine the reason for the reduced Npt2b protein expression, we hypothesized that ATP, which is a substrate of Akp3, is involved in regulating Npt $2 \mathrm{~b}$ expression. Luminal ATP levels were higher in both the proximal and distal intestine of $\mathrm{Akp3}^{-/}$mice compared with Akp3 ${ }^{+/+}$mice (Fig. 4E and 4F), as described previously [33]. The intestinal cellular ATP level did not differ significantly between $\mathrm{Akp} 3^{+/+}$ mice and Akp3 $\%$ mice (data not shown).

Purine nucleotides are well established extracellular signaling molecules [47]. P2X purinoceptor 7 (P2X7) is a member of the family of ionotropic ATP-gated receptors that localizes at the apical membrane of the epithelial cells of the mouse ileum [43, 47]. To examine whether ATP suppresses Npt2b expression, we used the normal rat cell line IEC-6. We detected P2X7 protein expression in the distal intestine and kidney of normal mice (Fig. $5 \mathrm{~A})$ and also in the distal intestine of $\mathrm{Akp3}^{+/+}$and Akp3 ${ }^{\%}$ mice (Fig. 5B). Npt2b and P2X7 receptor were also detected in normal rat cell line IEC-6 cells (Fig. 5C). The P2X7 receptor agonist (BzATP) suppressed Npt2b protein levels in IEC-6 cells (Fig. 5D). 


\section{Kidney Blood Pressure Research}

Fig. 3. Biologic parameters for $\mathrm{Ca}$ and Pi homeostasis in $\mathrm{Akp3}^{+/+}$and Akp3\% mice. Metabolic cages were used for 24-h food intake, urine and feces collection from male $\mathrm{Akp3}^{+/+}$and $\mathrm{Akp3}^{\%}$ mice 9-10 weeks of age $(n=5-$ 6/group). (A) Food intake, (B) urine volume, (C) plasma Cre, (D) ionized $\mathrm{Ca}$, (E) urinary Ca excretion, (F) fecal Ca excretion, (G) plasma $\mathrm{Pi},(\mathrm{H})$ urinary Pi excretion, (I) fecal Pi excretion, (J) plasma intact FGF23, (K) plasma intact

PTH,

and (L) plasma $1,25(\mathrm{O} \mathrm{H})_{2} \mathrm{D}_{3}$. Values are mean \pm SE. $\quad * \mathrm{p}<0.05$. Real-time PCR (M) $1 \alpha$-hydroxylase $(1 \alpha \mathrm{OHse}$ and $(\mathrm{N})$ 24 - hydroxyl a s e (240Hase) mRNA levels in the kidneys of male $\mathrm{Akp3}^{+/+}$ and $\mathrm{Akp3}^{\%}$ mice at $9-10$ weeks of age ( $n=5-6 /$ group) were assessed by real-time PCR. GAPDH was used as an internal control. Values are mean \pm SE. ${ }^{*} \mathrm{p}<0.05$.
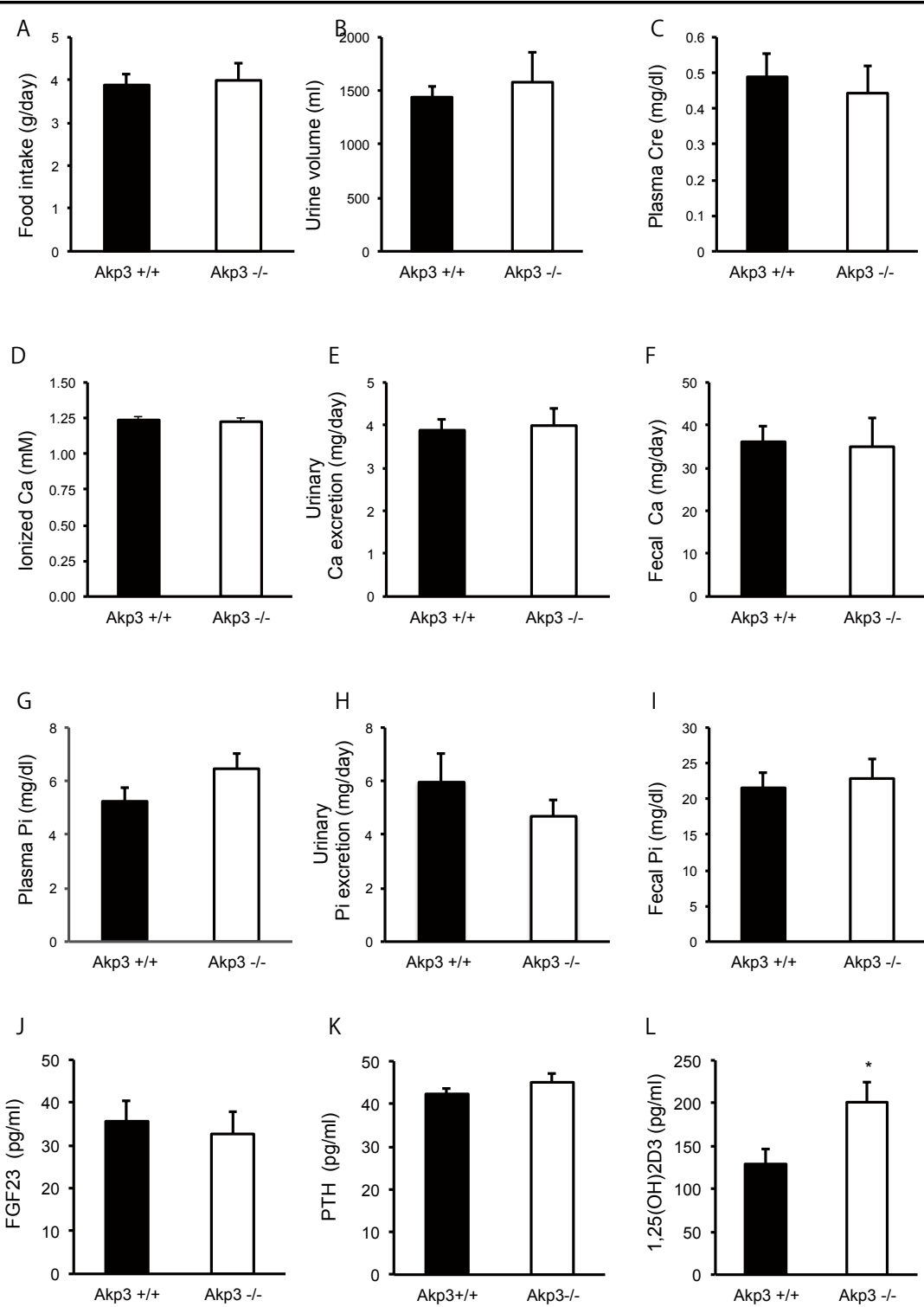

K
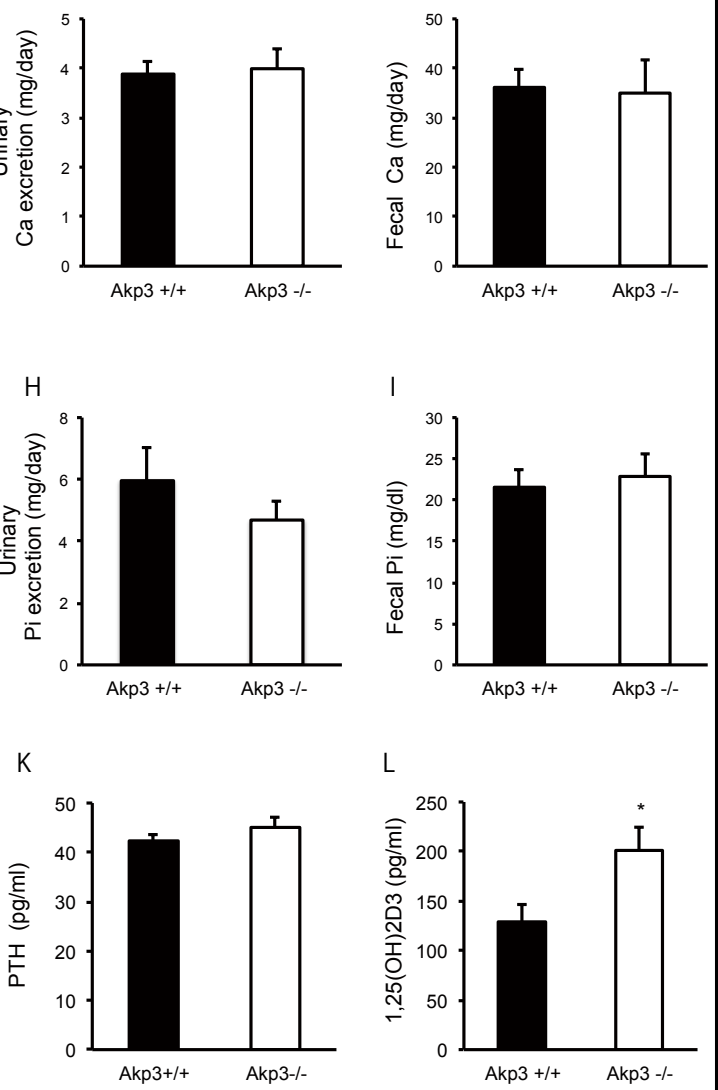

L

M

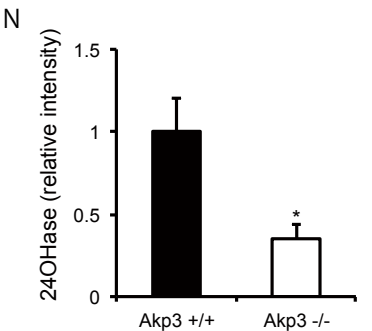




\section{Kidney Blood Pressure Research}

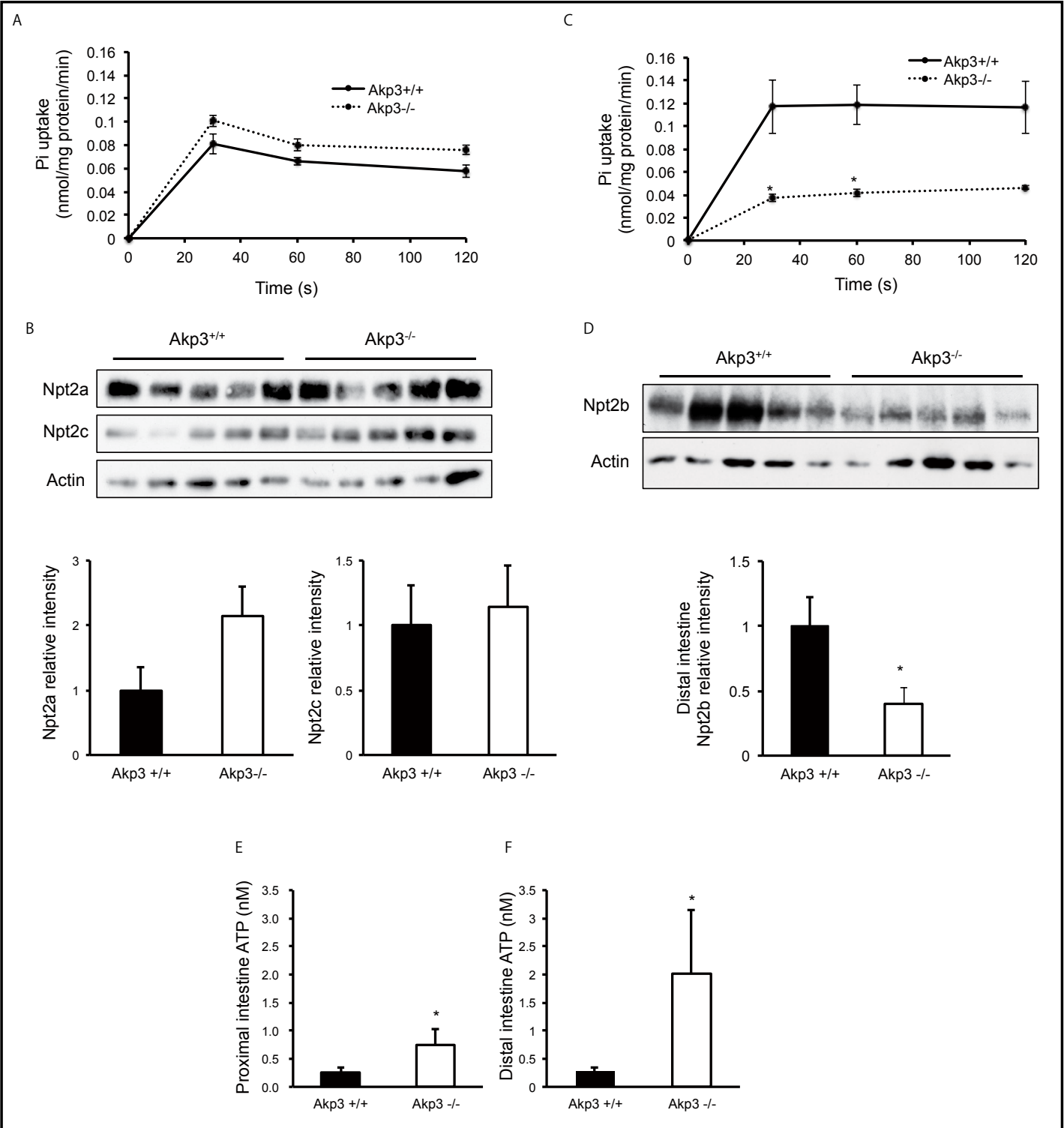

Fig. 4. Renal and intestinal $\mathrm{Pi}$ transport activity and transporter expression levels in $\mathrm{Akp} 3^{+/+}$and $\mathrm{Akp3}^{\%-}$ mice. BBMVs were isolated from the kidney and distal intestine of male $\mathrm{Akp}^{+/+}$and $\mathrm{Akp} 3^{\%}$ mice 9-10 weeks of age $(n=5-6)$. (A and C) Time-course of sodium-dependent Pi transport was examined using kidney and distal intestine. Values were mean \pm SE, ${ }^{*} \mathrm{p}<0.05$. (B and D) Western blotting analysis of renal and intestinal sodium-dependent Pi transporters. Each lane was loaded with $20 \mu \mathrm{g}$ of BBMV. Actin was used as the internal control. Relative intensity values were mean $\pm \mathrm{SE},{ }^{*} \mathrm{p}<0.05$. Luminal ATP concentration levels in the proximal (E) and distal (F) intestine of male $A \mathrm{kp3}^{+/+}$and Akp3 ${ }^{-/-}$mice 9-10 weeks of age. Data are presented as means $\pm \mathrm{SE}$. ${ }^{*} \mathrm{p}<0.05, \mathrm{n}=4-6 /$ group. 


\section{Kidney Blood Pressure Research}

Fig. 5. Expression of $\mathrm{Npt} 2 \mathrm{~b}$ and P2X7 receptor. Western blotting analysis. BBMVs isolated were the proximal and distal intestine, and the kidneys of WT mice. (B) BBMVs were isolated from the distal intestine of male $\mathrm{Akp3}^{+/+}$ and $\mathrm{Akp}^{-/}$mice 9-10 weeks of age. (C) Western blotting analysis. Npt2b and P2X7 receptor were detected in normal rat IEC-6 cells. For the experiment, total protein was extracted 2, 4, and 6 days after the cells reached $100 \%$ confluence. (D) For the experiment, total protein was extracted 6 days after $100 \%$ confluence. IEC- 6 cells were stimulated with $100 \mu \mathrm{M}$ BzATP. Western blotting analysis. Data are represented as means $\pm \mathrm{SE}$. ${ }^{*} \mathrm{p}<0.05$ compared with the non-stimulated control.

Several studies report that the loss of intestinal Npt2b delays the progression of kidney disease $[11,12,14]$. As shown in Fig. 4C and 4D, Akp3\% mice exhibited reduced intestinal BBMV Pi transport activity and Npt2b protein expression. We used an experimental mouse model having adenine-induced renal failure with hyperphosphatemia in Akp3\% mice to observe the progression of renal failure (Fig. 6). As described in the Materials and Methods, adenine was orally administered to $\mathrm{Akp}^{+/+}$and $\mathrm{Akp} 3^{-/}$mice. In the $\mathrm{Akp}^{+/+}$adenine-treated group, plasma Cre and $\mathrm{Pi}$ concentrations were significantly increased compared with the $\mathrm{Akp3}^{+/+}$control group and Akp3 $\%$ control and adenine-treated groups (Fig. 6A and 6B). In the $\mathrm{Akp3}^{+/+}$adenine-treated group, intestinal Akp3 protein expression was not changed, and $\mathrm{Npt} 2 \mathrm{~b}$ protein expression was significantly suppressed compared with the Akp3 $3^{+/}$control group (Fig. 6C-6E). The Npt2b protein levels did not differ significantly between the Akp3\% control and adenine-treated groups (Fig. 6C and 6E).

Finally, we performed in vivo absorption study using oral administration of ${ }^{32} \mathrm{P}$ in $\mathrm{Akp3}^{+/+}$and Akp3 ${ }^{\%}$ mice (Fig. 7). In intact animals, the rates of Pi absorption did not differ significantly between the $\mathrm{Akp}^{+/+}$and $\mathrm{Akp} 3^{-/}$mice (Fig. 7A). In the $\mathrm{Akp3}^{+/+}$mice with adenine-induced renal failure, the rates of $\mathrm{Pi}$ absorption $\left({ }^{32} \mathrm{P}\right.$ transfer from intestine to the blood) were not altered compared with those in the vehicle-treated $\mathrm{Akp} 3^{+/+}$mice (Fig. 7B). In contrast, in $\mathrm{Akp}^{-/}$mice with adenine-induced renal failure, the rates of Pi absorption ${ }^{32} \mathrm{P}$ transfer from intestine to the blood) were significantly decreased compared with those in the vehicle-treated Akp3 $\%$ mice (Fig. 7B). Thus, a significant reduction in Pi absorption was observed in $\mathrm{Akp}^{-\%}$ mice with renal failure. 


\section{Kidney Blood Pressure Research}

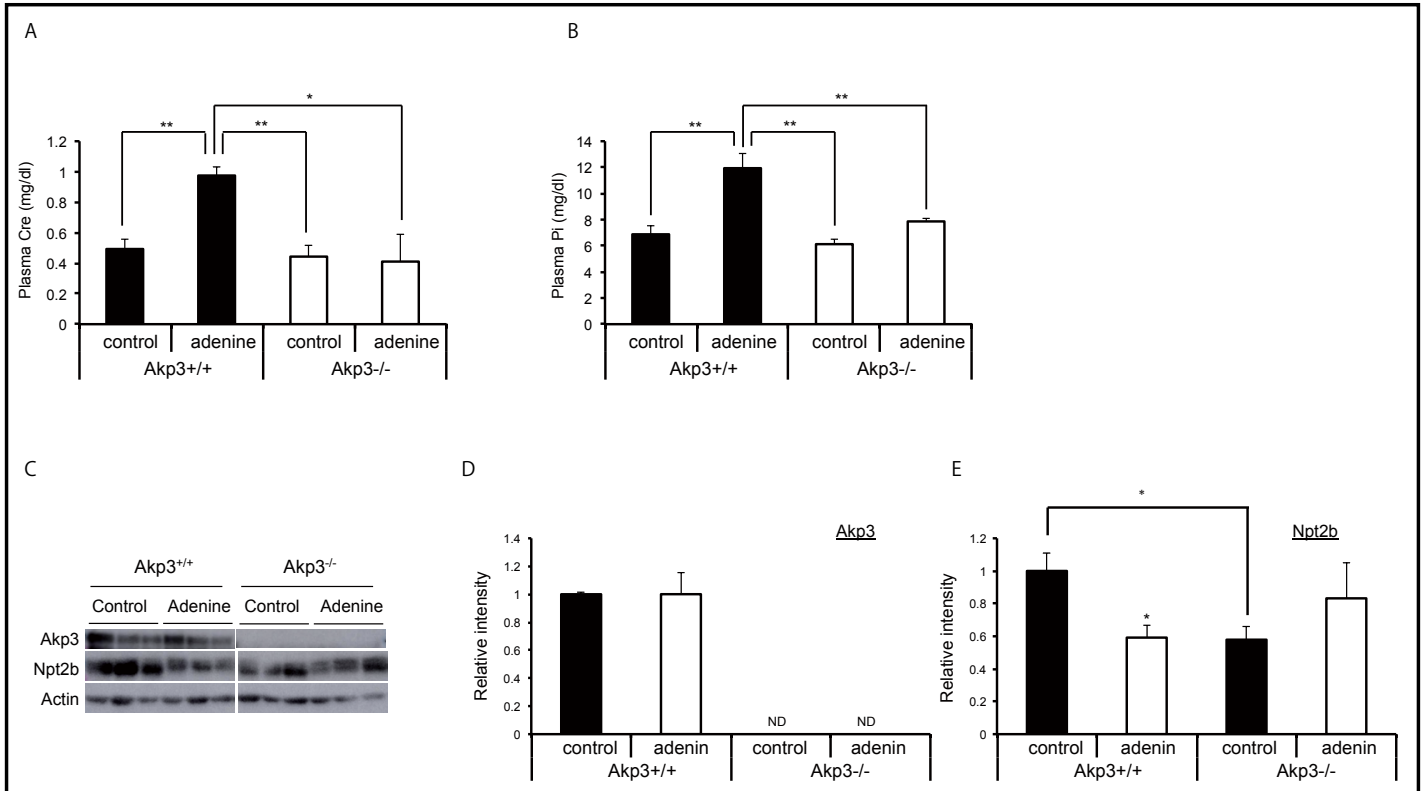

Fig. 6. Adenine-induced renal failure in $\mathrm{Akp3}^{+/+}$and $\mathrm{Akp} 3^{-/}$mice. Plasma Cre (A) and plasma Pi (B) levels at the end of the study are shown. Values are means \pm SE. ${ }^{*} p<0.05, p^{* *}<0.01$, (C-E) Intestinal Akp3 and Npt2b protein expression levels were assessed by Western blotting analysis. Male mice 9-10 weeks of age $(n=5-7$ / group) were used. Each lane was loaded with $20 \mu \mathrm{g}$ of BBMV. Actin was used an internal control. ND, not detected. Values are means \pm SE. ${ }^{*} \mathrm{p}<0.05$.

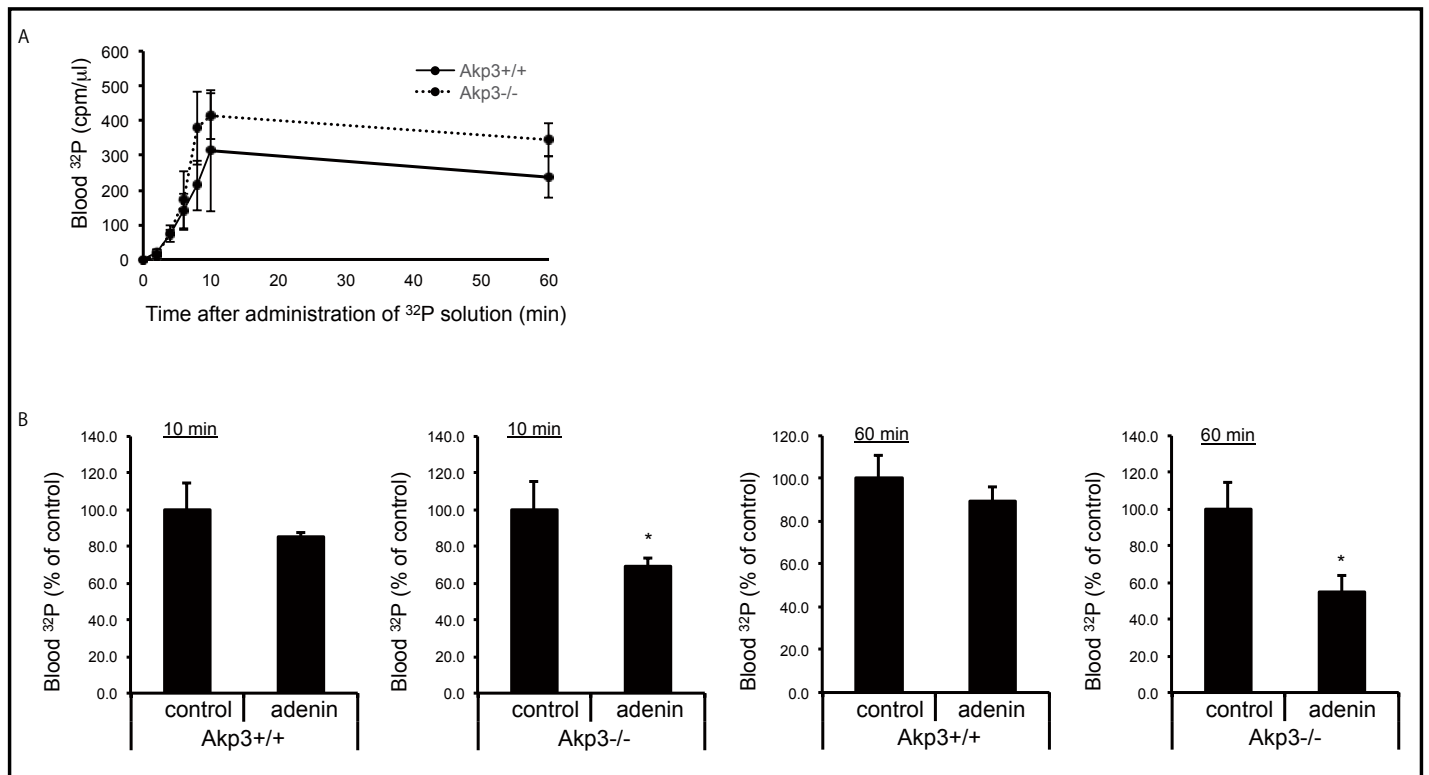

Fig. 7. In vivo intestinal $\mathrm{Pi}$ absorption in $\mathrm{Akp3}^{+/+}$and $\mathrm{Akp} 3^{\%}$ mice. (A) Intestinal phosphate absorption assays in $\mathrm{Akp3}^{+/+}$and $\mathrm{Akp3}^{-/-}$mice. Change in the blood $\mathrm{Pi}(\mathrm{cpm})$ after administration of ${ }^{32} \mathrm{P}$. Values are mean $\pm \mathrm{SE}, \mathrm{n}=4-6$. (B) Intestinal phosphate absorption assays in $\mathrm{Akp3}^{+/+}$and $\mathrm{Akp3}^{-/}$mice with adenine-induced renal failure at 10 and 60 min after administration of the test solution. Values are mean $\pm \mathrm{SE},{ }^{*} \mathrm{p}<0.05, \mathrm{n}=4$ 5. 


\section{Kidney Blood Pressure Research}

Kidney Blood Press Res 2018;43:1409-1424

\begin{tabular}{l|l}
\hline DOI: $10.1159 / 000493379$ & (C) 2018 The Author(s). Published by S. Karger AG, Basel
\end{tabular} Published online: 10 September, 2018 www.karger.com/kbr

\section{Discussion}

Our findings revealed that dietary Pi levels control intestinal Npt2b and Akp3 in a similar direction. Deletion of the Akp3 gene suppresses intestinal Npt2b protein and sodium-dependent Pi co-transport activities in isolated BBMVs. The reduced Pi absorption may stimulate an increase in the plasma active vitamin $\mathrm{D}$ concentration by suppressing 24-hydroxylase mRNA levels in the kidney. Furthermore, increases in the plasma Pi concentration were significantly suppressed in Akp3 $3^{-}$mice with adenine-induced renal failure compared with $\mathrm{Akp}^{+/+}$mice. In the $\mathrm{Akp} 3^{-/}$mouse adenine-induced renal failure model, the rate of transfer of ${ }^{32} \mathrm{P}$-labeled $\mathrm{Pi}$ from the intestine to the blood was significantly decreased compared with that of the Akp3\% control mice. Thus, Akp3 is predicted to be an important factor in intestinal Pi handling.

In Npt2b KO mice, the active vitamin D and fecal Pi excretion levels were significantly increased and FGF23, PTH, and urinary Pi excretion levels are significantly suppressed compared with wild-type mice [11]. In the present study, we demonstrated that Akp3\% mice with reduced Npt2b levels in the small intestine had decreased BBMV sodium-dependent transport activity and increased active vitamin D levels. We observed no changes in the plasma Pi, PTH, and FGF23 levels and fecal and urinary Pi excretion levels, however, in $\mathrm{Akp}^{-/}$mice. We expect that the difference in the responsiveness of vitamin D metabolism between Npt2b KO and Akp3 $\%$ mice depends on their different levels of suppression of sodium-dependent Pi absorption.

In addition, in adenine-induced hyperphosphatemic model mice, the increase in the plasma Pi concentration was significantly suppressed in Akp3\% mice. These data indicate that Pi transfer from intestinal epithelial cells to the blood may be affected by deletion of the Akp3 gene. Similar findings were obtained in Npt2b-deletion mice [11, 12]. In Npt2bdeletion mice, the increase in the plasma Pi concentrations was significantly suppressed in an adenine-induced renal failure model $[11,12]$. Taken together, these findings suggest that active Pi transport in the small intestine is decreased in Akp3 ${ }^{-/}$mice, and that suppression of Akp3 could be a novel Pi regulator in the renal failure model.

In mice, Akp3 is mainly expressed as a duodenal-specific IAP, while Npt2b is located in the ileum $[17,18,24,28]$. Thus, the functional sites of both molecules are different. Akp3 is thought to be secreted from the duodenum, however, and to function in the intestinal lumen. In Escherichia coli and yeast, alkaline phosphatase or acid phosphatase is secreted, catalyzes a Pi-containing compound, and efficiently transports the released Pi from the cell membrane [48]. In the mouse small intestine, we speculate that secreted Akp3 from the duodenum and upper jejunum catalyze Pi-containing compounds and release inorganic $\mathrm{Pi}$, which is efficiently absorbed in the ileum. It is expected that a system for digesting such $\mathrm{Pi}$ compounds is present in the proximal part and that the liberated inorganic Pi is absorbed in the distal part of the small intestine.

In our previous study, Npt $2 \mathrm{~b}$ KO did not affect $\mathrm{Pi}$ absorption within the range of $\mathrm{Pi}$ concentrations that normally occurs after meals, but significantly decreased urinary $\mathrm{Pi}$ excretion in mice [49]. We suggested that abnormal Pi metabolism might be involved in tight junction molecules, such as claudins, that are affected by Npt2b deletion [49]. In the present study, Akp $3 \%$ mice did not have excessive levels of Pi fecal excretion and hypophosphatemia compared with $\mathrm{Akp3}^{+/+}$mice. Although further studies are necessary, it is possible that intestinal Pi absorption, such as by the paracellular system, compensates for the loss of intestinal Npt2b in Akp3\% mice.

Based on this study, it is not clear how deletion of Akp3 leads to the suppression of ileum Npt2b. Previous studies reported that extracellular or intracellular nucleic acids such as ATP and NAD regulate $\mathrm{Na}^{+}$-dependent Pi transport activities or/and sodium-dependent transporter expression $[34,50]$. To investigate the mechanisms involved in the suppression of $\mathrm{Npt} 2 \mathrm{~b}$ protein in intestinal epithelial cells in Akp $3 \%$ mice, we analyzed the luminal concentration of ATP. Because ATP, ADP, and nucleotides are well-known substrates of IAP, 


\section{Kidney Blood Pressure Research}

the lack of Akp3 increases luminal ATP concentrations. Cellular ATP levels in the intestinal cells of Akp3 $\%$ mice were not different from those in $\mathrm{Akp3}^{+/+}$mice (data not shown). In a previous study, Malo et al. reported that luminal ATP concentrations are significantly increased in Akp $3^{\%}$ mice [33]. They confirmed that local Akp3 bioactivity creates a luminal environment that promotes the growth of a wide range of organisms [33]. Therefore, it is possible that luminal ATP and other nucleotides downregulate intestinal Pi absorption. In fact, inhibition of IAP inhibits intestinal Pi transport [38].

More recently, Brun et al. showed that Akp3 ${ }^{\%}$ mice display higher intestinal Ca uptake and Ca retention [51]. Some previous reports indicate that high dietary Ca concentrations decrease Pi digestibility and absorption [52, 53]. Furthermore, Uekawa et al. demonstrated that luminal ATP metabolism regulates transcellular Ca transport in the intestine by an $1,25(\mathrm{OH})_{2} \mathrm{D}_{3}$-independent mechanism in response to dietary Pi levels [54]. They reported that, in cultured intestinal epithelial cells, low Pi increased ATP in the apical side medium and allowed Ca entry into epithelial cells via the P2X7 receptor, resulting in increased Ca transport [54]. In the present study, the P2X7 receptor agonist suppressed Npt2b protein levels in IEC cells. In these contexts, in the present study, Akp3\% mice showed high ATP concentrations in the intestinal lumen, suggesting that luminal ATP levels affect intestinal $\mathrm{Ca}$ and Pi transport. Further research is necessary to determine the factors and mechanisms involved in the inhibition of intestinal $\mathrm{Npt} 2 \mathrm{~b}$ and sodium-dependent transport activity in $\mathrm{Akp}^{\%}$ mice.

Finally, in the present study, Akp3\%- mice exhibited suppressed Npt2b protein expression and intestinal sodium-dependent transport. This mouse model is important for elucidating intestinal Pi absorption mediated by $\mathrm{Npt} 2 \mathrm{~b}$. It is unclear why intestinal Npt2b protein is reduced in $\mathrm{Akp}^{-/}$mice, and further studies are needed to evaluate this point. Although the Akp3 ${ }^{-/}$mice exhibited suppressed renal 24-hydroxylase and intestinal Npt2b protein levels, the physiologic effect on Akp3 $\%$ mice appeared to be less important for Pi homeostasis under normal conditions because we did not detect plasma Pi concentrations and fecal Pi levels in intact Akp3 ${ }^{-/}$mice. In the renal failure model, however, Akp3 deletion significantly suppressed Pi absorption (the transfer of Pi from the intestine to the blood). We suggest that Akp3 has more important roles in Pi absorption in the renal failure model than in normal conditions.

Furthermore, it is necessary to clarify whether the importance of Akp3 for Pi homeostasis is unique to the mouse or if this is the case in rats as well (as a potential model for human intestinal Pi absorption). Intestinal Akp3 may be an important target for the treatment of CKDassociated hyperphosphatemia. A better understanding of the regulatory molecules involved in intestinal Pi handling will elucidate novel treatment targets for hyperphosphatemia other than Pi binders.

\section{Acknowledgements}

We thank Ms. Shihoko Yuki, Kumiko Morifuji, and Yuri Kusaka for their technical assistance. This work was supported by the Ministry of Education, Culture, Sports, Science, and Technology of Japan (No. 23689045 to H. Segawa, No. 26293204 to K. Miyamoto), and The Salt Science Research Foundation (No. 1322 to K. Miyamoto).

\section{Disclosure Statement}

The authors declare they have no conflicts of interest regarding this paper. 


\section{Kidney \\ Blood Pressure Research}

Sasaki et al.: Relationship Between Akp3 and Npt2b in the Gut

\section{References}

1 Waheed AA, Pedraza F, Lenz O, Isakova T: Phosphate control in end-stage renal disease: barriers and opportunities. Nephrol Dial Transplant 2013;28:2961-2968.

2 Haider DG, Lindner G, Wolzt M, Ahmad SS, Sauter T, Leichtle AB, Fiedler GM, Fuhrmann V, Exadaktylos AK: Hyperphosphatemia Is an Independent Risk Factor for Mortality in Critically Ill Patients: Results from a Cross-Sectional Study. PLoS One 2015;10:e0133426.

-3 Ketteler M, Block GA, Evenepoel P, Fukagawa M, Herzog CA, McCann L, Moe SM, Shroff R, Tonelli MA, Toussaint ND, Vervloet MG, Leonard MB: Executive summary of the 2017 KDIGO Chronic Kidney DiseaseMineral and Bone Disorder (CKD-MBD) Guideline Update: what's changed and why it matters. Kidney Int 2017;92:26-36.

-4 Inker LA, Astor BC, Fox CH, Isakova T, Lash JP, Peralta CA, Kurella Tamura M, Feldman HI: KDOQI US commentary on the 2012 KDIGO clinical practice guideline for the evaluation and management of CKD. Am J Kidney Dis 2014;63:713-735.

5 Isakova T, Nickolas TL, Denburg M, Yarlagadda S, Weiner DE, Gutierrez OM, Bansal V, Rosas SE, Nigwekar S, Yee J, Kramer H: KDOQI US Commentary on the 2017 KDIGO Clinical Practice Guideline Update for the Diagnosis, Evaluation, Prevention, and Treatment of Chronic Kidney Disease-Mineral and Bone Disorder (CKD-MBD). Am J Kidney Dis 2017;70:737-751.

6 Wagner CA, Hernando N, Forster IC, Biber J: The SLC34 family of sodium-dependent phosphate transporters. Pflugers Arch 2014;466:139-153.

7 Marks J, Debnam ES, Unwin RJ: The role of the gastrointestinal tract in phosphate homeostasis in health and chronic kidney disease. Curr Opin Nephrol Hypertens 2013;22:481-487.

$>8$ Kaneko I, Tatsumi S, Segawa H, Miyamoto KI: Control of phosphate balance by the kidney and intestine. Clin Exp Nephrol 2017;21:21-26.

>9 Sabbagh Y, Giral H, Caldas Y, Levi M, Schiavi SC: Intestinal phosphate transport. Adv Chronic Kidney Dis 2011;18:85-90.

-10 Matsuo A, Negoro T, Seo T, Kitao Y, Shindo M, Segawa H, Miyamoto K: Inhibitory effect of JTP-59557, a new triazole derivative, on intestinal phosphate transport in vitro and in vivo. Eur J Pharmacol 2005;517:111119.

11 Sabbagh Y, O'Brien SP, Song W, Boulanger JH, Stockmann A, Arbeeny C, Schiavi SC: Intestinal npt2b plays a major role in phosphate absorption and homeostasis. J Am Soc Nephrol 2009;20:2348-2358.

12 Ohi A, Hanabusa E, Ueda O, Segawa H, Horiba N, Kaneko I, Kuwahara S, Mukai T, Sasaki S, Tominaga R, Furutani J, Aranami F, Ohtomo S, Oikawa Y, Kawase Y, Wada NA, Tachibe T, Kakefuda M, Tateishi H, Matsumoto K, et al.: Inorganic phosphate homeostasis in sodium-dependent phosphate cotransporter Npt2b(+)/(-) mice. Am J Physiol Renal Physiol 2011;301:F1105-1113.

13 Hernando N, Myakala K, Simona F, Knopfel T, Thomas L, Murer H, Wagner CA, Biber J: Intestinal Depletion of NaPi-IIb/Slc34a2 in Mice: Renal and Hormonal Adaptation. J Bone Miner Res 2015;30:1925-1937.

14 Schiavi SC, Tang W, Bracken C, O'Brien SP, Song W, Boulanger J, Ryan S, Phillips L, Liu S, Arbeeny C, Ledbetter S, Sabbagh Y: Npt2b deletion attenuates hyperphosphatemia associated with CKD. J Am Soc Nephrol 2012;23:1691-1700.

-15 Marks J, Lee GJ, Nadaraja SP, Debnam ES, Unwin RJ: Experimental and regional variations in Na+dependent and $\mathrm{Na}+$-independent phosphate transport along the rat small intestine and colon. Physiol Rep 2015;3:pii:e12281.

16 Marks J, Srai SK, Biber J, Murer H, Unwin RJ, Debnam ES: Intestinal phosphate absorption and the effect of vitamin D: a comparison of rats with mice. Exp Physiol 2006;91:531-537.

17 Radanovic T, Wagner CA, Murer H, Biber J: Regulation of intestinal phosphate transport. I. Segmental expression and adaptation to low-P(i) diet of the type IIb $\mathrm{Na}(+)-\mathrm{P}(\mathrm{i})$ cotransporter in mouse small intestine. Am J Physiol Gastrointest Liver Physiol 2005;288:G496-500.

-18 Stauber A, Radanovic T, Stange G, Murer H, Wagner CA, Biber J: Regulation of intestinal phosphate transport. II. Metabolic acidosis stimulates $\mathrm{Na}(+)$-dependent phosphate absorption and expression of the $\mathrm{Na}(+)-\mathrm{P}(\mathrm{i})$ cotransporter NaPi-IIb in small intestine. Am J Physiol Gastrointest Liver Physiol 2005;288:G501-506. 


\section{Kidney \\ Blood Pressure Research}

19 Borowitz SM, Ghishan FK: Phosphate transport in human jejunal brush-border membrane vesicles. Gastroenterology 1989;96:4-10.

20 Borowitz SM, Ghishan FK: Maturation of jejunal phosphate transport by rat brush border membrane vesicles. Pediatr Res 1985;19:1308-1312.

21 Candeal E, Caldas YA, Guillen N, Levi M, Sorribas V: Intestinal phosphate absorption is mediated by multiple transport systems in rats. Am J Physiol Gastrointest Liver Physiol 2017;312:G355-G366.

-22 Bilski J, Mazur-Bialy A, Wojcik D, Zahradnik-Bilska J, Brzozowski B, Magierowski M, Mach T, Magierowska K, Brzozowski T: The Role of Intestinal Alkaline Phosphatase in Inflammatory Disorders of Gastrointestinal Tract. Mediators Inflamm 2017;2017:9074601.

23 Lalles JP: Intestinal alkaline phosphatase: novel functions and protective effects. Nutr Rev 2014;72:82-94.

-24 Narisawa S, Hoylaerts MF, Doctor KS, Fukuda MN, Alpers DH, Millan JL: A novel phosphatase upregulated in Akp3 knockout mice. Am J Physiol Gastrointest Liver Physiol 2007;293:G1068-1077.

25 Narisawa S, Huang L, Iwasaki A, Hasegawa H, Alpers DH, Millan JL: Accelerated fat absorption in intestinal alkaline phosphatase knockout mice. Mol Cell Biol 2003;23:7525-7530.

26 Wilcox FH: Genetics of alkaline phosphatase of the small intestine of the house mouser (Mus musculus). Biochem Genet 1983;21:641-652.

27 Buchet R, Millan JL, Magne D: Multisystemic functions of alkaline phosphatases. Methods Mol Biol 2013;1053:27-51.

28 Nakano T, Inoue I, Koyama I, Kanazawa K, Nakamura K, Narisawa S, Tanaka K, Akita M, Masuyama T, Seo M, Hokari S, Katayama S, Alpers DH, Millan JL, Komoda T: Disruption of the murine intestinal alkaline phosphatase gene Akp3 impairs lipid transcytosis and induces visceral fat accumulation and hepatic steatosis. Am J Physiol Gastrointest Liver Physiol 2007;292:G1439-1449.

-29 Lynes M, Narisawa S, Millan JL, Widmaier EP: Interactions between CD36 and global intestinal alkaline phosphatase in mouse small intestine and effects of high-fat diet. Am J Physiol Regul Integr Comp Physiol 2011;301:R1738-1747.

-30 Kaufmann CM, Grassmann J, Treutter D, Letzel T: Utilization of real-time electrospray ionization mass spectrometry to gain further insight into the course of nucleotide degradation by intestinal alkaline phosphatase. Rapid Commun Mass Spectrom 2014;28:869-878.

31 Yegutkin GG: Nucleotide- and nucleoside-converting ectoenzymes: Important modulators of purinergic signalling cascade. Biochim Biophys Acta 2008;1783:673-694.

-32 Zimmermann H: ATP and acetylcholine, equal brethren. Neurochem Int 2008;52:634-648.

33 Malo MS, Moaven O, Muhammad N, Biswas B, Alam SN, Economopoulos KP, Gul SS, Hamarneh SR, Malo NS, Teshager A, Mohamed MM, Tao Q, Narisawa S, Millan JL, Hohmann EL, Warren HS, Robson SC, Hodin RA: Intestinal alkaline phosphatase promotes gut bacterial growth by reducing the concentration of luminal nucleotide triphosphates. Am J Physiol Gastrointest Liver Physiol 2014;306:G826-838.

34 Lee YJ, Park SH, Jeung TO, Kim KW, Lee JH, Han HJ: Effect of adenosine triphosphate on phosphate uptake in renal proximal tubule cells: involvement of PKC and p38 MAPK. J Cell Physiol 2005;205:68-76.

-35 Friedlander G, Couette S, Coureau C, Amiel C: Mechanisms whereby extracellular adenosine 3',5'-monophosphate inhibits phosphate transport in cultured opossum kidney cells and in rat kidney. Physiological implication. J Clin Invest 1992;90:848-858.

-36 De Young MB, Scarpa A: Extracellular ATP activates coordinated $\mathrm{Na}+\mathrm{Pi}$, and $\mathrm{Ca} 2+$ transport in cardiac myocytes. Am J Physiol 1991;260:C1182-1190.

-37 Storelli C, Murer H: On the correlation between alkaline phosphatase and phosphate transport in rat renal brush border membrane vesicles. Pflugers Arch 1980;384:149-153.

38 Shirazi SP, Beechey RB, Butterworth PJ: The use of potent inhibitors of alkaline phosphatase to investigate the role of the enzyme in intestinal transport of inorganic phosphate. Biochem J 1981;194:803-809.

39 Kempson SA, Kim JK, Northrup TE, Knox FG, Dousa TP: Alkaline phosphatase in adaptation to low dietary phosphate intake. Am J Physiol 1979;237:E465-473.

40 Silva IV, Cebotaru V, Wang H, Wang XT, Wang SS, Guo G, Devuyst O, Thakker RV, Guggino WB, Guggino SE: The ClC-5 knockout mouse model of Dent's disease has renal hypercalciuria and increased bone turnover. J Bone Miner Res 2003;18:615-623.

41 Segawa H, Kaneko I, Takahashi A, Kuwahata M, Ito M, Ohkido I, Tatsumi S, Miyamoto K: Growth-related renal type II Na/Pi cotransporter. J Biol Chem 2002;277:19665-19672. 


\section{Kidney \\ Blood Pressure Research}

42 Van Cromphaut SJ, Dewerchin M, Hoenderop JG, Stockmans I, Van Herck E, Kato S, Bindels RJ, Collen D, Carmeliet P, Bouillon R, Carmeliet G: Duodenal calcium absorption in vitamin D receptor-knockout mice: functional and molecular aspects. Proc Natl Acad Sci U S A 2001;98:13324-13329.

-43 Bourzac JF, L'Eriger K, Larrivee JF, Arguin G, Bilodeau MS, Stankova J, Gendron FP: Glucose transporter 2 expression is down regulated following P2X7 activation in enterocytes. J Cell Physiol 2013;228:120-129.

-44 Gendron FP, Mongrain S, Laprise P, McMahon S, Dubois CM, Blais M, Asselin C, Rivard N: The CDX2 transcription factor regulates furin expression during intestinal epithelial cell differentiation. Am J Physiol Gastrointest Liver Physiol 2006;290:G310-318.

-45 Kaliannan K, Hamarneh SR, Economopoulos KP, Nasrin Alam S, Moaven O, Patel P, Malo NS, Ray M, Abtahi SM, Muhammad N, Raychowdhury A, Teshager A, Mohamed MM, Moss AK, Ahmed R, Hakimian S, Narisawa S, Millan JL, Hohmann E, Warren HS, et al.: Intestinal alkaline phosphatase prevents metabolic syndrome in mice. Proc Natl Acad Sci U S A 2013;110:7003-7008.

46 Thomas L, Wagner CA, Biber J, Hernando N: Adaptation of Opossum Kidney Cells to Luminal Phosphate: Effects of Phosphonoformic Acid and Kinase Inhibitors. Kidney Blood Press Res 2016;41:298-310.

47 Volonte C, Apolloni S, Skaper SD, Burnstock G: P2X7 receptors: channels, pores and more. CNS Neurol Disord Drug Targets 2012;11:705-721.

48 Oshima Y: The phosphatase system in Saccharomyces cerevisiae. Genes Genet Syst 1997;72:323-334.

49 Ikuta K, Segawa H, Sasaki S, Hanazaki A, Fujii T, Kushi A, Kawabata Y, Kirino R, Sasaki S, Noguchi M, Kaneko I, Tatsumi S, Ueda O, Wada NA, Tateishi H, Kakefuda M, Kawase Y, Ohtomo S, Ichida Y, Maeda A, et al.: Effect of Npt2b deletion on intestinal and renal inorganic phosphate (Pi) handling. Clin Exp Nephrol 2018;22:517528.

50 Nomura K, Tatsumi S, Miyagawa A, Shiozaki Y, Sasaki S, Kaneko I, Ito M, Kido S, Segawa H, Sano M, Fukuwatari T, Shibata K, Miyamoto K: Hepatectomy-related hypophosphatemia: a novel phosphaturic factor in the liver-kidney axis. J Am Soc Nephrol 2014;25:761-772.

51 Brun LR, Lombarte M, Roma S, Perez F, Millan JL, Rigalli A: Increased calcium uptake and improved trabecular bone properties in intestinal alkaline phosphatase knockout mice. J Bone Miner Metab 2017; DOI:10.1007/s00774-017-0887-7.

52 Jenkins KJ, Phillips PH: The mineral requirements of the dog. II. The relation of calcium, phosphorus and fat levels to minimal calcium and phosphorus requirements. J Nutr 1960;70:241-246.

53 Boswald LF, Dobenecker B, Clauss M, Kienzle E: A comparative meta-analysis on the relationship of faecal calcium and phosphorus excretion in mammals. J Anim Physiol Anim Nutr (Berl) 2018;102:370-379.

54 Uekawa A, Yamanaka H, Lieben L, Kimira Y, Uehara M, Yamamoto Y, Kato S, Ito K, Carmeliet G, Masuyama R: Phosphate-dependent luminal ATP metabolism regulates transcellular calcium transport in intestinal epithelial cells. FASEB J 2018;32:1903-1915. 